\title{
High-Rate Performance All-Solid-State Li-SeS 2 Battery with Selenium sulphide/three-dimensional graphene as cathode material
}

\author{
Wenyan $\mathrm{Li}^{1}$, Fangchao Liu ${ }^{1, *}$, Zhongli Shen ${ }^{1}, \mathrm{Han} \mathrm{Hu}^{1}$ and Zhengwen $\mathrm{Fu}^{2}$ \\ ${ }^{1}$ School of Materials Engineering, Shanghai University of Engineering Science, Shanghai 201600, P.R \\ China; \\ ${ }^{2}$ Department of Chemistry, Shanghai Key Laboratory of Molecular Catalysis and Innovative \\ Materials, Fudan University, Shanghai, 200433, P.R China. \\ "E-mail: $\underline{84309286 @ q q . c o m}$
}

doi: $10.20964 / 2021.07 .58$

Received: 13 March 2021 / Accepted: 6 May 2021 / Published: 31 May 2021

Selenium sulfide $\left(\mathrm{SeS}_{2}\right)$ shows attractive advantages of high capacity for lithium storage. Here, a freestanding ultra-high dispersion Selenium sulfide three-dimensional graphene $\left(\mathrm{SeS}_{2}-3 \mathrm{DG}\right)$ was synthesized and used as a cathode material in all-solid-state Lithium-Selenium sulfide $\left(\mathrm{Li}-\mathrm{SeS} \mathrm{S}_{2}\right)$ batteries for enhancing rate performance and utilization of $\mathrm{SeS}_{2}$. $\mathrm{SeS}_{2}-3 \mathrm{DG}$ achieved the utilization rate of $103 \%$ with capacity of $1,163 \mathrm{mAh} \mathrm{g}^{-1}$ and remained $538.56 \mathrm{mAh} \mathrm{g}^{-1}$ after 20 cycles under $1 / 2 \mathrm{C}$. It should be noted that $\mathrm{SeS}_{2}-3 \mathrm{DG}$ exhibited outstanding rate performance, which discharged under $7 \mathrm{C}$ with capacity as high as $990 \mathrm{mAh} \mathrm{g}^{-1}$. Due to the high utilization rate of $\mathrm{SeS}_{2}$, charge and discharge products of Li$\mathrm{SeS}_{2}$ batteries were observed by high-resolution transmission electron microscopy (HRTEM) and selected area electron diffraction (SAED). The mechanism of lithium sulfide ( $\left.\mathrm{Li}_{2} \mathrm{~S}\right) /$ Lithium selenide $\left(\mathrm{Li}_{2} \mathrm{Se}\right) \leftrightarrow \mathrm{SeS}_{2}$ was confirmed.

Keywords: Ultra-high dispersion, All-solid-state, $\mathrm{Li}_{-} \mathrm{SeS}_{2}$ batteries, Charge and discharge products, High utilization

\section{$\underline{\text { FULL TEXT }}$}

(C) 2021 The Authors. Published by ESG (www.electrochemsci.org). This article is an open access article distributed under the terms and conditions of the Creative Commons Attribution license (http://creativecommons.org/licenses/by/4.0/). 